\title{
Ebstein's anomaly with significant dysplasia of the tricuspid valve presenting at 73 years of age. A case report
}

\author{
Lumír Koc ${ }^{a, b}$, Jiří Ondrášekc, Tomáš Zatočil ${ }^{a}$, Anna Nečasováa, Jindřich Špinar ${ }^{a, b}$
}

${ }^{a}$ Department of Internal Medicine - Cardiology, University Hospital, Brno

${ }^{b}$ Faculty of Medicine, Masaryk University, Brno

${ }^{3}$ Center of Cardiovascular and Transplant Surgery, Brno

\section{ARTICLE INFO}

Article history:

Submitted: 27. 7. 2017

Accepted: 11. 8. 2018

Available online: 6. 6. 2019

\section{Klíčová slova:}

Dysplazie trojcípé chlopně

Ebsteinova anomálie

Náhrada trojcípé chlopně

Nedomykavost trojcípé chlopně

\section{SOUHRN}

Ebsteinova anomálie (EA) je vzácná vrozená srdeční vada, charakterizovaná změnou polohy trojcípé chlopně posunuté směrem $k$ hrotu pravé komory (PK); jejím doprovodným znakem je obvykle nedomykavost chlopně. Zatímco její závažné formy s extrémně dilatovanou funkční PK a útlakem levých srdečních oddílů vedou $\mathrm{k}$ rozvoji těžkého srdečního selhání v nízkém věku a - v některých případech - dokonce již prenatálně, mohou se osoby s mírnou EA dožít vysokého věku, aniž by byla tato vada diagnostikována. Popisujeme prípad pacienta s mírnější formou EA a príspěvkem dysplazie, u něhož bylo toto onemocnění zjištěno až v sedmém decenniu, kdy u něj došlo k rozvoji srdečního selhání doprovázeného významnou regurgitací trojcípé chlopně. Po náhradě trojcípé chlopně biologickou protézou a uzávěru defektu mezisíňové přepážky došlo k významnému zlepšení funkce PK a ústupu pacientových obtíží.

(c) 2019, ČKS.

\section{ABSTRACT}

Ebstein's anomaly (EA) is a rare congenital heart defect, characterized by an anomalous tricuspid valve displaced towards the apex of the right ventricle (RV); it is usually accompanied by regurgitation. While its severe forms with an extremely dilated functional RV and oppression of the left heart chambers result in the development of severe heart failure at a young age and, in some cases, even prenatally, patients with mild EA may live until old age with the condition unrecognized. We present the case of a patient with a milder form of EA and a contribution of dysplasia, with the disease undiagnosed until his eighties when he developed heart failure accompanied by significant tricuspid regurgitation. Tricuspid valve replacement with a bioprosthesis and atrial septal defect occlusion were followed by significant improvement of RV function and remission of the patient's problems.
Ebstein's anomaly

Tricuspid regurgitation

Tricuspid valve dysplasia

Tricuspid valve replacement $\mathrm{mm} / \mathrm{m}^{2}$ of body surface area relative to the mitral valve annulus. ${ }^{3}$ The resultant functional RV dilatation and oppression of the other cardiac chambers are suggestive of the severity of the condition. While echocardiographic assessment of the ratio of the right atrium (RA) area to that of the remaining cardiac chambers is the basis of the Celermajer index (where grade 1 is the mildest form), the four-grade classification proposed by Carpentier ${ }^{5}$ (with type A denoting the mildest form) includes evaluation of RA and RV sizes; additionally, the classification takes into account the tricuspid valve leaflet morphology and mobility. Treatment of significant forms of EA is surgical, with valve-sparing surgery preferred. Right atrial reduction by transverse plication of its free wall and construction of a monocuspid valve were performed by Danielson in 1972; ${ }^{6}$ however, the technique was not applicable to all morphological variants of EA. A revolution in the treatment of EA came with the technique of cone tricuspid valve reconstruction according to Da Silva; the procedure can be performed with very low morbidity and mortality

Address: Lumír Koc, MD, Department of Internal Medicine - Cardiology, Faculty of Medicine, Masaryk University and University Hospital Brno, Jihlavská 20, 62500 Brno, e-mail: koc.lumir@fnbrno.cz DOI: 10.1016/j.crvasa.2018.07.004 
rates. ${ }^{7}$ The procedure, generally based on Carpentier's technique, consists in mobilization and reposition of tricuspid valve leaflets to form a cone, with the size of the atrialized $\mathrm{RV}$ reduced by longitudinal plication. In cases where reconstruction is unfeasible, the tricuspid valve can be replaced by a bioprosthesis; this procedure is undertaken particularly in elderly patients. ${ }^{8,9}$ In patients with a small and dysfunctional $\mathrm{RV}$, the ventricle can be unloaded by creating a bidirectional cavopulmonary conduit (BCPA) deriving venous return from the superior vena cava right to the pulmonary artery; alternatives include total cavopulmonary conduit (TCPC) or heart transplantation. ${ }^{10}$ The time to disease presentation is dependent on its severity. Severe disease presents as early as the period of fetal development or early after birth and, not exceptionally, the patient does not survive until adulthood. ${ }^{4}$ On the other hand, there have been reports of patients surviving to old age with the defect unrecognized..$^{11}$ Below is the case report of a patient with mild EA and a contribution of dysplasia, in whom the defect did not manifest itself until he was in his eighties.

\section{Case report}

A 73-year-old man with EA was referred to our center for progressively deteriorating dyspnea. The patient was not

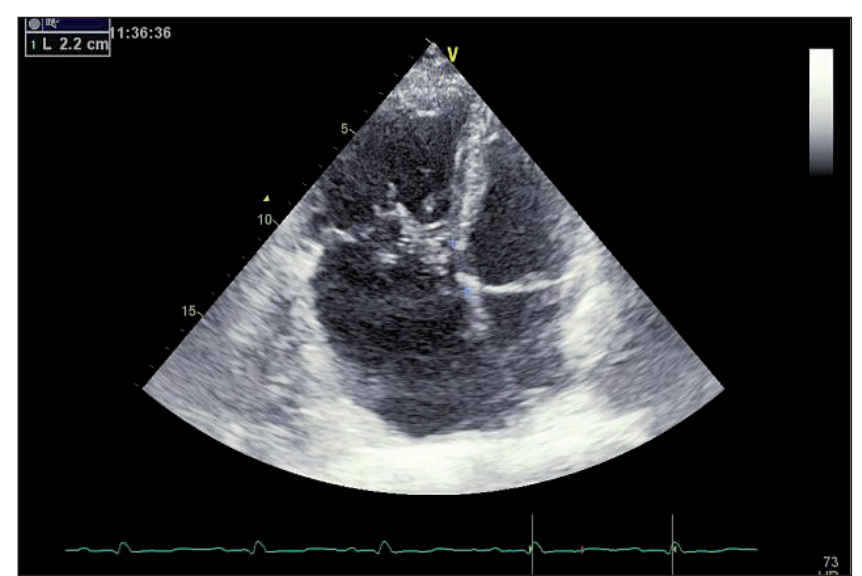

Fig. 1 - Apical displacement of a functional tricuspid annulus by $22 \mathrm{~mm}$ (i.e. $11.2 \mathrm{~mm} / \mathrm{m}^{2}$ ) relative the mitral annulus. limited by the condition throughout his lifetime; he led an active life practicing sports and working, prior to retirement, as a foreman in a foundry. In 2003, he experienced non-ST elevation myocardial infarction managed conservatively. Subsequently, he was on follow-up by a cardiologist and the diagnosis of EA was established. Given the mild form of his condition, the patient continued to be on follow-up only. In April 2014, he had selective coronary angiography because of exertional chest pain; the procedure identified 30-40\% stenosis of the left anterior descending artery, $40 \%$ stenosis of the circumflex branch of the left coronary artery, 30-40\% stenosis of the right coronary artery, and chronic occlusion of the right posterolateral branch, all managed conservatively. In the same year, the patient had an electrophysiological study because of focal atrial tachycardia; however, no accessory atrioventricular pathways or arrhythmogenic substrate eligible for radiofrequency ablation were identified. In early autumn 2015, his dyspnea began to deteriorate to be experienced by the patient after walking several dozen meters on a flat surface. At the same time, the patient complained of markedly deteriorated angina, which was why he was referred to our center to undergo comprehensive assessment. In addition to his cardiac diagnoses, the patient was receiving treatment for chronic obstructive pulmonary disease, hypertension, hyperlipoproteinemia, and hyperuricemia.

Echocardiography revealed elongation of tricuspid valve leaflets bound to RV walls by accessory chordae, apical displacement of a functional tricuspid valve annulus by $22 \mathrm{~mm}$ relative to the mitral valve annulus and apical displacement of leaflet coaptation (Fig. 1) with massive tricuspid regurgitation (Fig. 2A). The right heart chambers were significantly dilated (Fig. 3A) oppressing left heart chambers (Fig. $3 \mathrm{C}$ ). Using the Celermajer index, the patient had EA grade 2 or type A according to Carpentier's classification (Fig. 4).

To objectivize the dyspnea, the patient undertook 6-minute walking test (6MWT) covering $317 \mathrm{~m}$ and showing significantly decreased peripheral oxygen saturation, from $90 \%$ to $77 \%$. Additionally, the patient experienced angina attacks resolving once the test was discontinued and sublingual nitroglycerin administered.

To make the assessment complete, the patient had repeat coronary angiography with a stationary finding on the coronary arteries, no progression since the previous

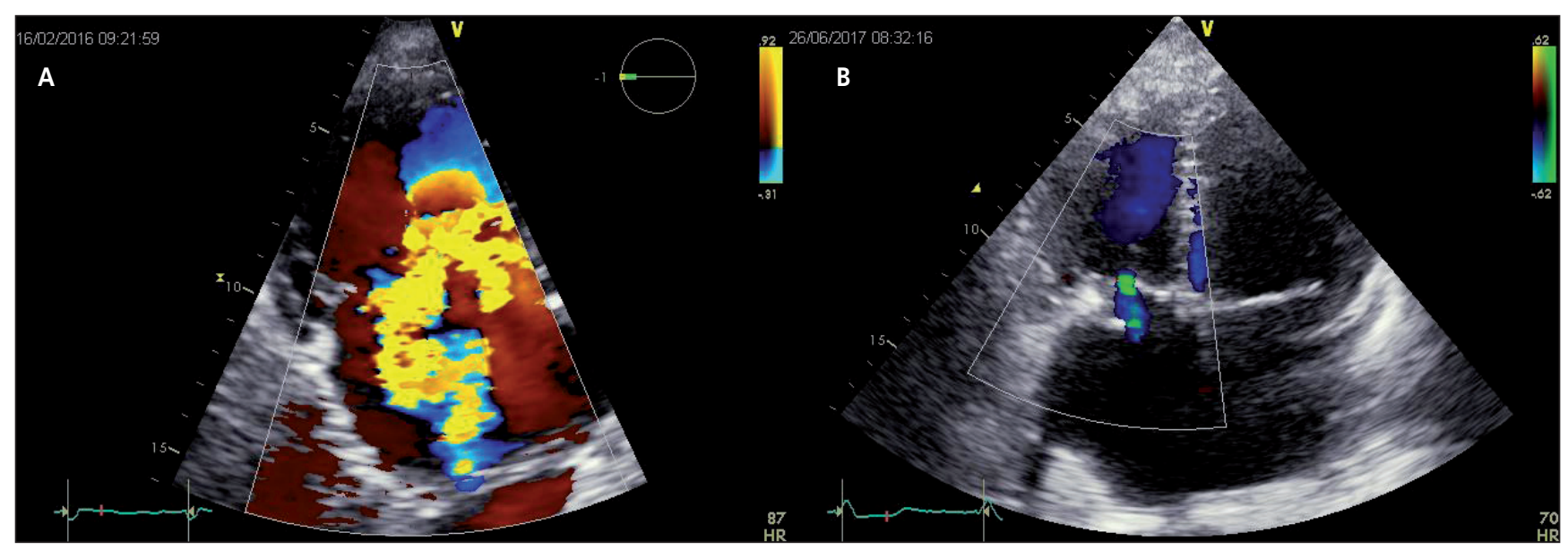

Fig. 2 - Tricuspid regurgitation. (A) Massive jet prior to surgery. (B) Small jet after tricuspid valve replacement. 

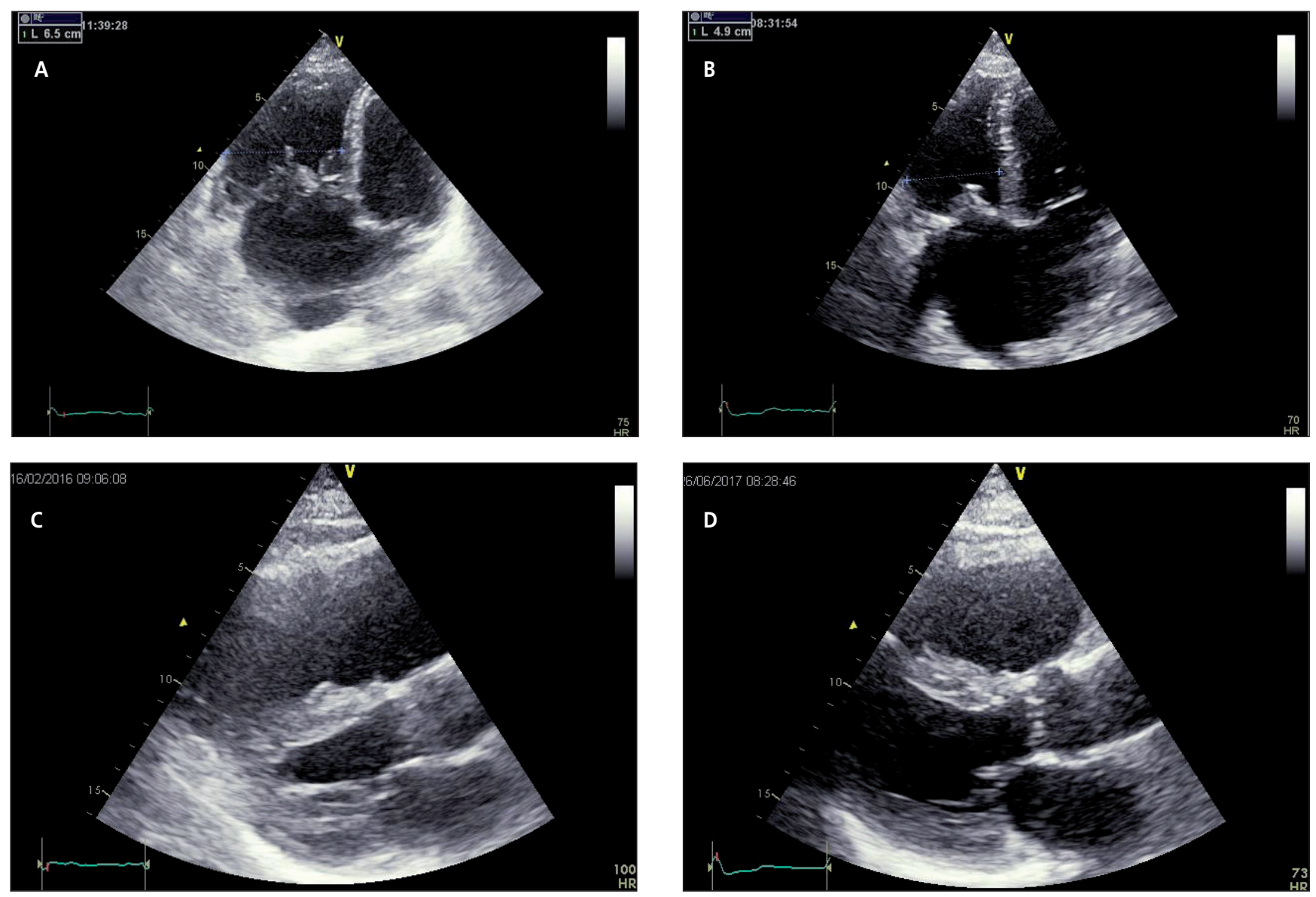

Fig. 3 - Heart chambers before and after surgery. (A) Markedly dilated right ventricle (baseline diameter, $65 \mathrm{~mm}$ ), oppressed left ventricle, prior to surgery, apical projection. (B) Reduced right ventricle (baseline diameter, $49 \mathrm{~mm}$ ) and resolution of oppression of left heart chambers after tricuspid valve replacement, apical projection. (C) Right ventricular dilatation and left ventricular oppression prior to surgery, parasternal projection, long axis. (D) Reduction of the right ventricle and enlargement of the left ventricle after surgery, parasternal projection, long axis.

examination and, as documented by right-heart catheterization, absence of pulmonary hypertension.

Given the symptoms and significant regurgitation, the patient was indicated for tricuspid valve replacement. The cardiac surgical procedure revealed tricuspid valve septal leaflet displacement to the RV, anomalous papillary muscles, and anterior tricuspid cusp calcification. This was managed by excision of almost the entire valve followed by bio-

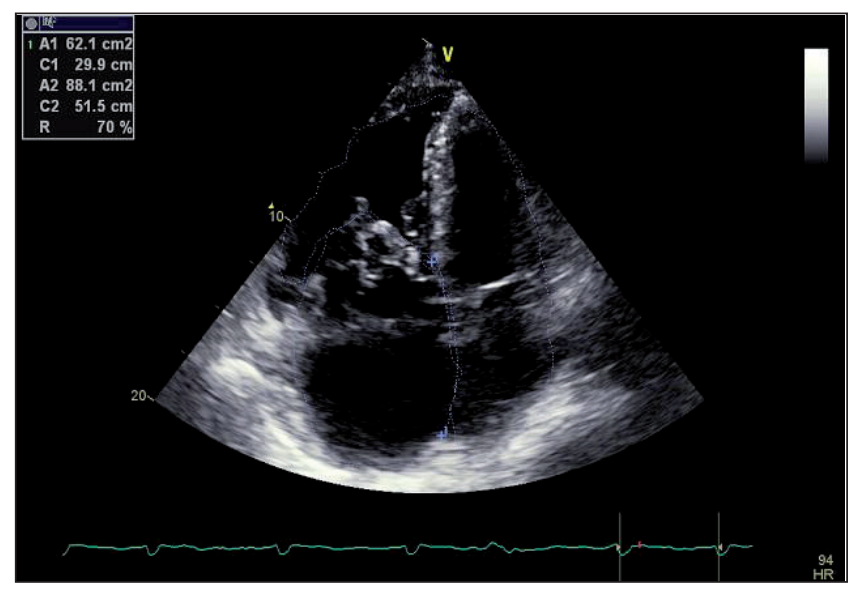

Fig. 4 - Celermajer index of EA, apical projection, end-diastole. The ratio of the right atrial area to that of the other heart chambers is 0.7, which corresponds to grade 2 . prosthetic valve (EL Perimount 33, St Jude Medical, St. Paul, MN, USA) implantation. The atrial septal defect was closed using continuous suture. In the postoperative course, the patient developed persistent complete AV block managed by pacemaker implantation from mini-thoracotomy by implanting an epicardial lead above the RV outflow tract.

The procedure was followed by significantly improved exercise capacity of the patient, resolution of the dyspnea (to NYHA I-II), longer distance covered in 6MWT (424 m, i.e., increase by $34 \%$ ) without exertion-related desaturation. The patient no longer experienced any chest pain while his resting oxygen saturation normalized (from 90 to 99\%). Follow-up echocardiography documented resolving regurgitation (Fig. 2B), appreciable RV reduction (Figs 3B, 3D) though with persisting mild systolic dysfunction, and a reduced RA. Most importantly though, the size and certainly also the output of left heart chambers were increasing (Figs 3B, 3D).

\section{Discussion}

In patients with EA surviving to retirement age without the defect manifesting itself, the condition is a mild form with a good. ${ }^{4}$ Using both the Celermajer index, and Carpentier classification, our patient had mild EA. The tricuspid valve was also dysplastic. Tricuspid valve dysplasia is characterized by nodular thickening of the leaflets or their focal de- 
fects, the chordae may be involved as well. Some patients may show a dilated tricuspid annulus. However, in contrast to EA, pure dysplasia is not associated with leaflet apical displacement towards the RV. ${ }^{3}$ Despite the mild form of the defect, the originally insignificant regurgitation in a territory exposed to such mechanical stress evolved into a severe defect. Permanent volume overload of the right heart chambers resulted in their dilatation, oppression of left heart chambers, and development of heart failure. Because of massive tricuspid regurgitation, RA pressure was higher than that in the left atrium which, in the presence of atrial septal defect, resulted in a right-to-left shunt and resting desaturation deteriorating on exertion.

Based on the echocardiographic finding and symptoms, surgery was indicated, a standard policy in patients with more severe-than-moderate tricuspid regurgitation and symptoms including class III and IV NYHA dyspnea, arrhythmia or deteriorated functional capacity on exercise testing. Further, surgery should also be considered in patients experiencing progressive dilatation of right heart chambers or deteriorating RV function irrespective of symptoms. Because of the significant dysplasia of the thickened and calcified anterior tricuspid valve leaflet, the generally preferred sparing procedure could not be undertaken; ${ }^{12}$ in these cases, the technique currently considered the procedure of the first choice is that developed by Da Silva. The patient had his valve replaced by a bioprosthesis. Valve repair using a bioprosthesis is performed, with excellent outcomes, particularly in elderly EA patients; given their life expectancy, need for re-do surgery for valve degeneration is not a concern while shorter surgical time is another plus of bioprosthesis implantation. Mechanical valve implantation is not recommended because of the high risk of thrombus formation in the low-pressure right-side vascular territory. ${ }^{13}$ Interatrial septal defects are associated with EA in up to $80 \%$ of cases; among other things, they may also be associated with paradoxical embolism. ${ }^{14}$ The indication in patients scheduled for surgery is occlusion.

The coronary artery involvement was not hemodynamically significant and a revascularization procedure was not indicated. The patient was presumably developing exertional angina secondary to heart failure; this was confirmed by the angina resolving once the defect had been corrected although a revascularization procedure had not been performed. A third-grade AV block as a potential and frequent complication following treatment of EA, can be managed by pacemaker implantation. ${ }^{15}$

Right atrial dilatation and RV dysfunction create arrhythmogenic substrate for the development of various forms of supraventricular and ventricular arrhythmias, which occur commonly in EA and which may be, especially in elderly patients, the first disease manifestation. ${ }^{4}$ As a rule, it is critical to search for pre-excitation signs as accessory pathways are present in up to $29 \%$ of EA patients. ${ }^{16}$ These pathways give rise to AV reentry tachycardias and are particularly dangerous because of the potential for rapid impulse conduction from the atrium to the ventricle when atrial fibrillation or flutter develop. Radiofrequency ablation of supraventricular arrhythmias in the presence of EA is associated with poorer outcomes than in patients with a healthy heart; in addition, recurrence is more common. ${ }^{17}$

\section{Conclusion}

Our case report shows that while CHD may have a dramatic presentation at a very advanced age, it can be successfully managed. Complex CHDs such as EA are to be treated at specialized centers.

\section{Conflict of interest}

None declared.

\section{Funding body}

None.

\section{Ethical statement}

Authors state that the research was conducted according to ethical standards.

\section{References}

1. Warnes CA, Williams RG, Bashore TM, et al. ACC/AHA 2008 guidelines for the management of adults with congenital heart disease: a report of the American College of Cardiology/ American Heart Association Task Force on Practice Guidelines (Writing Committee to Develop Guidelines on the Management of Adults With Congenital Heart Disease). J Am Coll Cardiol 2008;52:e143-e263.

2. Booker OJ, Nanda NC. Echocardiographic assessment of Ebstein's anomaly, Echocardiogr Mt Kisco N 2015;32(Suppl 2):S177-S188.

3. Edwards WD. Embryology and pathologic features of Ebstein's anomaly. Prog Pediatr Cardiol 1993;2:5-15.

4. Celermajer DS, Bull C, Till JA, et al. Ebstein's anomaly: presentation and outcome from fetus to adult. J Am Coll Cardiol 1994;23:170-176.

5. Chauvaud S, Berrebi A, d'Attellis N, et al. Ebstein's anomaly: repair based on functional analysis. Eur J Cardiothorac Surg 2003;23:525-531.

6. Danielson GK, Fuster V. Surgical repair of Ebstein's anomaly. Ann Surg 1982;196:499-504.

7. da Silva JP, Baumgratz JF, da Fonseca L, et al., The cone reconstruction of the tricuspid valve in Ebstein's anomaly. The operation: early and midterm results. J Thorac Cardiovasc Surg 2007;133:215-223.

8. Attenhofer Jost CH, Connolly HM, Scott CG, et al. Outcome of Cardiac Surgery in Patients 50 Years of Age or Older With Ebstein Anomaly. J Am Coll Cardiol 2012;59:2101-2106.

9. Brown ML, Dearani JA, Danielson GK, et al. The outcomes of operations for 539 patients with Ebstein anomaly. J Thorac Cardiovasc Surg 2008;135:1120-1136.e7.

10. Yuan SM. Ebstein's Anomaly: Genetics, Clinical Manifestations, and Management, Pediatr Neonatol 2016;58:211-215.

11. Adams JC, Hudson R. A case of Ebstein's anomaly surviving to the age of 79. Br Heart J 1956;18:129-132.

12. Baumgartner $\mathrm{H}$, Bonhoeffer $\mathrm{P}$, De Groot NM, et al., ESC Guidelines for the management of grown-up congenital heart disease (new version 2010): The Task Force on the Management of Grown-up Congenital Heart Disease of the European Society of Cardiology (ESC). Eur Heart J 2010;31:2915-2957.

13. Brown ML, Dearani JA, Danielson GK, et al. Comparison of the outcome of porcine bioprosthetic versus mechanical prosthetic replacement of the tricuspid valve in the Ebstein anomaly. Am J Cardiol 2009;103:555-561.

14. Attenhofer Jost CH, Connolly HM, Scott CG, et al. Increased risk of possible paradoxical embolic events in adults with Ebstein anomaly and severe tricuspid regurgitation. Congenit Heart Dis 2014;9:30-37.

15. Brickner ME, Hillis LD, Lange RA. Congenital heart disease in adults. Second of two parts. N Engl J Med 2000;342:334-342.

16. Khositseth A, Danielson GK, Dearani JA, et al. Supraventricular tachyarrhythmias in Ebstein anomaly: management and outcome. J Thorac Cardiovasc Surg 2004;128:826-833.

17. Attenhofer Jost CH, Connolly HM, Dearani JA, et al. Ebstein's Anomaly. Circulation 2007;115:277-285. 